\title{
Institutionelle logikker i biblioteksvæsenet og dets omverden \\ NPM vs. Bibliotekarisk praksis ${ }^{1}$
}

\author{
Af Nanna Kann-Christensen
}

\begin{abstract}
Artiklen analyserer hvordan eksempler på NPM-inspirerede forandringer i folkebibliotekerne mødes af ledere og bibliotekarer. Formålet med artiklen er dels at introducere begrebet institutionelle logikker i biblioteksforskningen, og dels at diskutere hvordan den bibliotekariske logik formes i mødet med NPM-inspirerede organisationsudviklingsprojekter. Når et felt mødes af forandringer, som udspringer af en anden tankegang end den, som er fremherskende i feltet, bliver feltets egne logikker og forestillinger om, hvad der er vigtigt, undertiden synlige. I artiklen diskuteres det, hvordan den bibliotekariske logik betyder, at der ikke automatisk øves modstand mod forandringer, men at bibliotekarerne, både på feltniveau og på organisationsniveau, står fast, når de oplever at blive truet på deres faglighed og deres muligheder for indflydelse.
\end{abstract}

Nanna Kann-Christensen er lektor ved Danmarks Biblioteksskole,nkc@db.dk.

\section{Indledning}

Når folkebiblioteket i dag indgår kontrakter om serviceniveau og mål med kommunen og arbejder aktivt med at tilpasse organisationen til omverdenens krav om effektivitet og omstillingsparathed, er det bl.a. fordi, arbejdet i den offentlige sektor i de sidste 20 år har været stærkt præget af New Public Management (NPM). Det har betydet, at den offentlige sektor har undergået en omfattende forandring. Hensigten med NPM-reformer er primært at gøre den offentlige sektor mere effektiv, og man kan identificere en generel tendens, hvor ideer om frit valg, øget responsivitet, fokus på brugeren, ny teknologi og decentralisering under samlebegrebet NPM indoptages af offentlige organisationer, både centralt og lokalt (Klausen, 2001, 2005, Ejersbo \& Greve, 2005). NPM-reformerne har på mange områder ændret den offentlige forvaltningspraksis radikalt. Eksempler på en ændret offentlig praksis er den øgede brug af kontraktstyring, udlicitering samt indførelsen af moderne ledelsesprincipper i institutionerne. Således kan NPM karakteriseres som en samlebetegnelse for en række initiativer, der har det tilfælles, at de udspringer af en nyliberalistisk tankegang, og har til formål at effektivisere den offentlige sektor ved hjælp af metoder og ideer fra den private sektor (Busch et al, 2005).

Mange folkebiblioteker arbejder desuden med organisationsudvikling, og dette sker delvist med udgangspunkt i NPM-orienterede krav (Audunson, 1996, Kann-Christensen, 2009, Pors, 2005, 2006). Når NPM - via den lokale organisationsudvikling 
holder sit indtog i bibliotekerne, mødes den af en bibliotekarisk identitet og kultur. Der sker, netop i disse år, et møde mellem en professionsidentitet og en NPM-tankegang i bibliotekerne. Biblioteksvæsenet har traditionelt været ledet og drevet af et fagbureaukrati med dybe rødder i en biblioteksprofessionel identitet og faglig stolthed (Emerek, 2001, Schreiber, 2006, Skouvig, 2006). Denne tradition kan betragtes som båret af en institutionaliseret bibliotekarprofessionel logik. Med NPM bølgen generelt - og gennemførelsen af en række konkrete organisationsudviklingsprojekter specifikt - bliver denne tradition udfordret og tvunget til omstilling.

Folkebiblioteket er ikke den eneste offentlige institution som har oplevet NPM-reformer. De fleste offentlige organisationer har måttet indarbejde nye normer og praksiser i forbindelse med NPM-reformer. Sundhedsvæsenet er, både i Danmark og mange andre steder reformeret kraftigt på grund af disse reformer og krav om fx professionel ledelse, dokumentation, kvalitetsmålinger etc. (se fx Reay \& Hinings (2005) og Bentzen et al.(1999)). Det er altså ikke en biblioteksspecifik problemstilling, som her behandles. Problemstillingen er generel, og findes i mange forskellige dele af den offentlige sektor. Denne artikel lægger sig i forlængelse af Røviks udlægning af den skandinaviske tilgang til institutionel teori (Røvik, 2005). Der trækkes på amerikansk institutionel teori, men den empiriske metode er et casestudie, som lægger vægt på mødet mellem to sæt af institutionaliserede forestillinger og analyserer den meningsdannelse, der foregår i dette møde.

Formålet med artiklen er dels at introducere begrebet institutionelle logikker i biblioteksforskningen, og dels at diskutere hvordan den bibliotekariske logik formes i mødet med NPM-inspirerede organisationsudviklingsprojekter. I det følgende introduceres derfor til begreberne NPM-logik og bibliotekarlogik. Herefter analyseres to eksempler på møder mellem disse logikker dels på feltniveau og dels på organisationsniveau. Således er mit fokus i artiklen primært den meningsdannelse, der foregår hos informanterne i mødet mellem de to logikker.

\section{Institutionelle logikker}

Institutionel teori har traditionelt beskæftiget sig med stabilitet og normer i organisationer og organisatoriske felter. I de senere år kan der dog identificeres en interesse $i$, at anvende et institutionelt perspektiv i forbindelse med forandringer i felter og organisationer (Reay \& Hinings, 2005, Thornton \& Ocasio, 2008). I forbindelse med studier af forandringer er begrebet institutionelle logikker velegnet. Thornton \& Ocasio (2008) definerer institutionelle logikker som socialt konstruerede mønstre af praksisser, antagelser og regler, som individer producerer og reproducerer deres omgivelser ud fra. M.a.o. et sæt spilleregler Der er altså et stort overlap mellem anvendelsen af begrebet logikker og begrebet institutioner (Alford \& Friedland, 1991).

Logikkerne understøtter forståelsen af, hvordan forskellige emner får mening i en organisation, ligesom de er bestemmende for, hvordan forskellige forhold $\mathrm{i}$ organisationen får opmcerksomhed (Thornton \& Ocasio, 2008). Logikkerne forsyner aktører i organisationen med et "regelsæt" og en række konventioner for, hvilke forhold der er vigtige og hvilke mindre vigtige, m.a.o. hvordan man skal fordele opmærksomheden. Institutionelle logikker er de underliggende antagelser, som skaber rammen for meningsdannelse. Logikkerne reproduceres gennem handling.

En forandring af institutionelle logikker forandrer kriterierne for legitimitet (Suddaby \& Greenwood, 2005). Suddaby og Greenwoods pointe er, at strategisk brug af sprog (retorik) både kan sikre eller underminere det nyes legitimitet. En pointe er, at der er et stærkt fokus på meningsskabelse og de institutionelle logikkers betydning herfor, både hos Thornton \& Ocasio og hos Suddaby \& Greenwood. En anden pointe er, at forandringerne i feltet kan studeres gennem feltets italesættelser af både det eksisterende og det nye. Logikker er således et velegnet begreb i forhold til at studere italesættelser af forandringer, da logikkerne vil præge fortolkningen og meningsdannelsen af forandringerne. Dette betyder, at et vigtigt iagttagelsesledende begreb $i$ analysen, som følger er "logik". Det er således betydningsdannelsen der er i fokus i analysen, - dvs. informanternes fortolkning af forandringerne der analyseres. Konkret bygger analysen på et større interviewmateriale, som er produceret med henblik på min ph.d.-afhandling (KannChristensen, 2009) Jeg har interviewet bibliotekarer og ledere, med henblik på at studere deres forestillinger om konkrete organisationsudviklingsprojekter.

I denne artikel er fokus, hvad der sker i mødet mellem en NPM-inspireret og en traditionel professions- 
baseret faglig bibliotekarlogik. Med udgangspunkt i institutionel teori undersøger jeg erfaringer med dette møde, som de fremtræder på feltniveau, og som de bliver fremstillet af en række informanter i biblioteksvæsenet, på organisationsniveau.

\section{New Public Management}

NPM-logikken bygger på en præmis om, at den offentlige sektor i begyndelsen af 1980erne efterhånden var blevet så stor, bureaukratisk og ineffektiv, at der måtte gøres noget. Løsenet blev at gøre den offentlige sektor mere smidig, decentral og bedre ledet, ved at prøve at få den offentlige sektor til at tage ved lære af den private sektor. Derved forstås, at reformbestræbelserne foregår ud fra en norm om, at en markedsgørelse af den offentlige sektor vil forbedre og effektivisere den, samt at ledelse og organisering $i$ den offentlige sektor skal lade sig inspirere af organisation og ledelsesformer, som de ser ud i den private sektor. Der er således et normativt element i NPM. Normen er den private sektor, og organisationer i den offentlige sektor må forholde sig til denne norm.

Klausen (2005) beskriver, hvordan hovedpunkterne i NPM hviler på 2 søjler. Den økonomiske og den ledelsesmæssige søjle.

Den økonomiske søjle omfatter dels bestræbelser på at markedsgøre det offentlige. Dette sker ud fra en forestilling om, at konkurrence mellem institutionerne vil forbedre kvaliteten af de ydelser, de leverer. Dels indeholder den økonomiske søjle bestræbelser på, at gøre den offentlige sektors virksomhed til genstand for måling, evaluering, sammenligning etc. Den bagvedliggende intention med disse bestræbelser er, at gøre produktion og ressourceanvendelse i staten mere styrbar, legitim og transparent (Jarlov og Melander, 2005).

Den ledelsesmoessige søjle omfatter dels et skift i forhold til tillid og aftaler, forstået på den måde, at kommunikation og sikring af overholdelse af politiske mål, i stigende grad bygges på kontrakter (og altså ikke på tillid). Herudover findes et øget fokus på strategi og udvikling. Ligesom ovenfor, hvor den private sektors kontrolmekanismer i form af markedskræfterne overtager en del af styringen i den offentlige sektor, ser man også i ledelsessøjlen, at ledelseskoncepter som er udviklet i den private sektor, anvendes i den offentlige sektor.
I det følgende tages primært udgangspunkt i den ledelsesmæssige søjle. Ifølge Busch et al (2005) har der i Skandinavien været større fokus på den ledelsesmæssige søjle, end den økonomiske. Den skandinaviske skole inden for institutionel teori betoner begrebet "translation" (oversættelse), som betegner det forhold, at ideer ("opskrifter") rejser mellem organisationer og i hver organisation bliver fortolket i overensstemmelse med de særlige betingelser, der gælder for hver enkelt organisation (Røvik, 1998). I denne tradition kan man argumentere for at det $\mathrm{i}$ veludviklede socialdemokratiske velfærdsstater, ville være lettere at vedtage nye ledelses opskrifter end at privatisere store dele af den velfærd, som er kernen i det offentlige system.

Nils Brunsson og Kerstin Sahlin-Andersson (2005) tilbyder et alternativ til denne institutionelle forklaring i en artikel, der har det provokerende formål at vise, hvordan offentlige institutioner og forvaltninger ikke er "rigtige" organisationer, og at NPM har til formål at omdanne disse til ægte organisationer, der har både identitet, hierarki og rationalitet.

Brunsson og Sahlin-Andersson argumenterer for, at den offentlige forvaltning mangler identitet og selvstændighed, idet den altid er et instrument for udførelsen af en politik. Man kan indvende, at biblioteker har mere karakter af organisationer med identitet, end en forvaltning har i traditionel forstand, men den offentlige institution kan betragtes som en arena, der i høj grad styres af professioner. Sådanne professionsstyrede arenaer er knyttet til professionelle normer, både mht. til hvem der kan rekrutteres, og hvad disse personer sidenhen gør. Således er ledelsen, i den typiske professionsstyrede organisation som Brunsson og Sahlin-Andersson beskriver, primært ledelse hvad angår administration, og ikke så meget hvad angår kerneydelsen. Derfor kan det forekomme, at ledelsen har det økonomiske ansvar, men har svært ved at styre økonomien. Disse parallelle hierarkier gør samordningen besværlig. Dette skyldes bl.a., at professioner har klare regler for, hvad som er passende, m.a.o. en fælles logik (DiMaggio \& Powell, 1991, March, 1995). De professionelle ved også, at de skal argumentere "rationelt", selvom disse argumenter sigter på professionelt bestemte mål, ikke nødvendigvis mod mål som er specifikke for den konkrete organisation. Dette betyder, at der kan være forskelle på hvad ledelsen anser som gode resultater, og hvad professionen anser som gode resultater. Bib- 
liotekarprofessionen har en stærk holdning til, hvad der er vigtigt i bibliotekerne, og denne holdning vil sandsynligvis være koblet netop til det bibliotekariske arbejde, og ikke til fx ønsket om effektiv administration (Audunson, 1996, Evald, 2007, Kann-Christensen, 2009). Det vil præge den fagprofessionelle ledelse, at aktørerne først og fremmest er forankrede i fagprofessionen og kun sekundært i ledelsesprofessionen (Klausen, 2001).

Det er her, de offentlige moderniseringsreformer kommer ind i billedet. Hvis man som Brunsson og Sahlin-Andersson anser det overordnede formål med NPM for at være at skabe identitet, hierarki og rationalitet i de offentlige organisationer, medvirker reformerne til:

At skabe identitet ved at skabe tydeligere grænser for organisationen $\mathrm{fx}$ ved at give lov til at de selv kan skaffe sig indtægter og råde over deres aktiver. Indtægtsdækket virksomhed og kontraktstyring med råderet over evt. overskud / selvfinansiering af evt. underskud, kan være eksempler på sådanne reformer.

At skabe hierarki ved at underminere de professionelles ret til at styre på professionens præmisser. Det, som mange betegner som djøfiseringen af samfundet, er en udvikling, som underminerer de professionelles status i offentlige organisationer. Én bestemt profession, nemlig "djøferne" som er uddannet til at administrere og evaluere får en forrang i organisationer der normalt er præget af andre professioner, $\mathrm{fx}$ bibliotekarer, læger eller forskere.

At skabe rationalitetsmål og resultater, og herved sætte fokus på at der er for mange og for modstridende mål i offentlig sektor. Mål, og kontraktstyring er de oplagte redskaber hertil, men også måling af resultater og fokus på evaluering kan sætte fokus på mål og rationalitet, selvom det nu også betvivles hvorvidt evalueringer og målinger faktisk er rationelle (Dahler Larsen 1998).

Disse tiltag er, som man kan se, primært hjemmehørende i Klausens ledelsessøjle.

NPM-logikken bygger således på et rationale om, at markedet er bedre til at skabe effektivitet og kvalitet end bureaukratiet, som den offentlige sektor traditionelt har brugt som styringsredskab. Ifølge NPM er brugeren kunde, og systemets mål er at levere de ydelser kunden efterspørger. Det betyder i yderste konsekvens, at alt hvad den offentlige sektor gør, burde være efterspørgselsstyret. I praksis er denne logik dog ofte modificeret af andre forhold såsom fagprofessionelle og økonomiske hensyn. I NPM-rationalet knyttes legitimitet til de offentlige organisationers og de offentligt ansattes evne til omstilling.

\section{Bibliotekarlogikken}

Mange forskere i Norden har beskæftiget sig med bibliotekernes rationaler, kamp for identitet, ligesom der er skrevet en del om biblioteksfeltets homogenitet. (se fx Andersson \& Skot Hansen, (1994), Audunson \& Lund (2001), Audunson, (1999) og Jochumsen \& Hvenegaard Rasmussen, (2006.))

Dette er et tema som der bygges videre på i antologien Bibliotekarerne (2005). Antologien handler om bibliotekarerne som profession, og viser bl.a., at bibliotekarerne, som før opfattede deres stilling som et kald, nu kæmper for at blive anerkendt som mere end blot servicemedarbejder. Man stræber efter at være rigtige professionelle med særlig viden og kompetence i forhold til søgning, genfinding og "teknologisk brugerorientering" (Schreiber, 2005). Bibliotekaren er blevet betegnet som en semiprofession eller en velfærdsprofession. Dvs. en erhvervsgruppe som udspringer af det moderne velfærdssamfund. Bibliotekarprofessionens stærke tilknytning til den offentlige sektor, som er under forandring, indebærer et konstant skift i fokus. Dette betyder, at bibliotekarernes selvforståelse til stadighed udfordres og omdefineres (Sundin, 2006). Eksempler på dette er forskellige kampagner for bibliotekarprofessionen. Fx BF's Bibliotekaren kan mange stillinger (Bibliotekarforbundet, 1998), og Danmarks Biblioteksskoles kampagne fra 2005 Bibliotekar.nu. Disse kampagner ser Sundin som et udtryk for en profession i forandring. Kampagnerne skal markere over for omverdenen, hvad bibliotekarerne nu kan. (Sundin, 2006). Jeg mener, at kampagnerne også kan betragtes som autokommunikation, dvs. til professionen selv og dermed at forandringerne i bibliotekarernes faglighed også skaber usikkerhed om professionens kerne.

Anders Ørom (1993) har også beskæftiget sig med bibliotekarernes forskellige identiteter. Han skriver, at der er to klassiske bibliotekaridentiteter på spil fra 1960'erne, nemlig Kulturformidleridentiteten og Fagreferentidentiteten. Disse identiteter er knyttet 
til et overblik over materialerne og kontakten med lånerne. Det er således det indholdsbaserede formidlingsarbejde, der er vigtigt for bibliotekarernes identitet. Ørom skriver videre, at fremkomsten af nye organisationsformer og teknologi på forskellig vis udfordrer disse identiteter. Teknologien, som anvendes i bibliotekerne, strider ikke nødvendigvis imod kulturformidlings- og fagreferentidentiteternes fokus på materialer og lånerkontakt, men teknologiens indmarch i folkebiblioteket har betydet, at et servicerationale, i mange tilfælde konkurrerer med det klassiske oplysningsrationale. Den elektroniske informationsformidling er nemlig i høj grad præget af en norm om "effektiv fysisk-tilgangeliggørelse af information" (Ørom, 1993, p. 40).

På trods af den omfattende forskning er det kompliceret at konstruere en arketypisk bibliotekarlogik (Greenwood \& Hinings, 1993). Bl.a. fordi bibliotekaridentiteten, som ovenfor vist, er flertydig og ustabil. Når det alligevel kan være interessant at iagttage glidninger inden for den bibliotekariske logik, er det fordi den bliver synlig og påvirkelig i mødet med en anden måske mere velfunderet logik, nemlig NPMlogikken. I det følgende analyseres derfor, hvordan reformer der kan siges at være båret af en NPM-logik, mødes af biblioteksvæsenet på feltniveau og af bibliotekarer på organisationsniveau. Herefter diskuteres det hvordan bibliotekarlogikken bliver synlig og hvad der sker i mødet mellem NPM og bibliotekarlogikken. Logikken fremtræder tydeligere når den formes og former i samspil med en anden logik.

I biblioteksvæsenet har der ikke været meget direkte debat om betydningen af NPM for det bibliotekariske arbejde og de fagprofessionelle normer, som jo på væsentlige punkter udfordres af det markedsorienterede NPM rationale (men som jeg vil vise i det følgende har der været en del indirekte protester). Der har dog været et par indlæg, typisk i Bibliotekspressen (Bibliotekarernes fagblad). Et eksempel på et sådant debatindlæg, fra perioden der her behandles er NPM udfordring eller trussel (Brücker og Нøy 2003). Denne artikel beskriver, hvorledes NPM opleves af gulvbibliotekaren. NPM-reformerne tager form af en uendelig strøm af nye ledelsesværktøjer og målemetoder. Alle disse tiltag gør det "svcerere og svcerere at pleje grundfunktionerne ... god service". Dvs. arbejde der ikke "omfatter kerneydelser og grundarbejde". Den vigtige pointe i denne og andre debatartikler inden for de senere år er, hvordan bibliotekarerne betoner, at NPM-reformerne stjæler tiden fra det vigtige. I den omtalte artikel er der også en gennemgående ideologisk modstand formet af bibliotekarprofessionens faglige normer mod de liberalistiske ideer i NPM, men hovedsagen er frustrationen over, at målinger, dokumentation og konkurrence flytter fokus fra service og formidling, med den konsekvens at service og kvalitet forringes. M.a.o. vil bibliotekarerne gerne udfylde deres professionelle rolle, at formidle viden og kultur og styrke demokratiet ved at sikre fri og lige adgang til bøger og andre medier. De ønsker, at legitimere sig, ikke i økonomiske termer, men snarere som en profession der er rundet af et velfærdsstatsligt oplysningsrationale, og som skal legitimere sig ved at tilbyde alle borgere, høj som lav en mulighed for viden og kultur (Schreiber, 2006, Emerek, 2006).

På sin vis er denne diskussion i det danske biblioteksvæsen ikke ny. Emerek (2001) skriver om de danske folkebibliotekers tidlige historie, hvordan to traditionshorisonter kæmper om at præge bibliotekerne. En modsætning mellem et værdirationale og instrumentelt rationale. Den kamp som beskrives i det følgende, handler på sin vis stadig om værdirationalitet vs. instrumentel rationalitet. Men den instrumentelle rationalitet handler ikke længere kun om rationel drift, fx forstået som en tayloristisk organisering af arbejdet, men om en forestilling om at metoder fra den private sektor, både hvad angår ledelse og økonomiske styringsværktøjer kan skabe bedre og mere effektive biblioteker for brugerne. Ligesom værdirationaliteten ikke længere handler om, at bibliotekarerne vil oplyse den uvidende befolkning med bøger af god kvalitet, men at de vil værne om de demokratiske idealer, via fx beskyttelse af ytringsfriheden, arbejde med integration, samtidig med at man holder sig ajour med medieudviklingen og formidle på nye spændende måder.

\section{Lov om biblioteksvirksomhed 2000}

I Lov om Biblioteksvirksomhed (og i den kulturministerielle udmøntning af den) kan der identificeres flere NPM-elementer. (Kann-Christensen, 2008, Kann-Christensen \& Andersen, 2009). I det følgende analyseres et udvalgt eksempel på, hvad der kan karakteriseres som NPM i loven. Det drejer sig om $\S 3$ stk. 3, som handler om ledelsen af folkebiblioteker. Eksemplet er valgt fordi det korresponderer med emnet for den følgende analyse, på feltniveau. 
$\S 3$ stk. 3 lyder: Lederen af et folkebibliotek skal have en relevant faglig baggrund. Dette lyder måske ikke specielt NPM-agtigt. Men det er en forandring af den tidligere lovs ordlyd om samme emne. Før 2000 skulle lederen af et folkebibliotek være uddannet bibliotekar. Med denne paragraf blev der åbnet mulighed for, at lederen af biblioteket kunne have en anden baggrund end faguddannede bibliotekarer. Med andre ord blev der lejlighed til, for fx professionelle ledere, at søge stillinger som bibliotekschefer. Dette element hører til den ledelsesmæssige søjle i NPM. Denne ændring medførte både debat og forskellige tiltag.

Den nævnte tidligere bestemmelse om bibliotekaruddannede ledere betyder, at der ved lovens vedtagelse udelukkende var bibliotekarer på lederstillingerne.

Selvom man kan hævde, at dette var en åbning for professionelle djøf-ledere på bibliotekerne, blev der også gjort noget for at efteruddanne de eksisterende bibliotekar-ledere. Således blev der i forbindelse med implementeringen af Lov om Biblioteksvirksomhed afsat 20 mio. kr. årligt til kompetenceudvikling, hvoraf en del blev brugt til lederuddannelse. Hovedaktiviteten var et uddannelsesforløb tilrettelagt i et samarbejde mellem Bibliotekslederforeningen Danmarks forvaltningshøjskole, Bibliotekarforbundet og Biblioteksstyrelsen. Uddannelsen blev gennemført 4 steder i landet med deltagelse af 75 biblioteksledere (Biblioteksstyrelsen, 2004). Nu skulle bibliotekarerne klædes på, til at kunne klare sig i konkurrencen med "djøferne" i det meget større felt af potentielle ansøgere til stillinger som ledere af de danske folkebiblioteker.

At loven åbner muligheden for andre faggrupper end bibliotekarer på posten som biblioteksleder, kan tolkes som et ønske om at åbne op for en mere professionel ledelse af bibliotekerne. Man ønsker mere fleksible og forandringsparate ledelsesstrukturer. Dette er i tråd med Kurt Klaudi Klausens ledelsessøjle i NPM (Klausen, 2001). Her kan man sige at lovens ændring kan forklares ved det, som Klaudi Klausen kalder for den tredje reformbølge. Det drejer sig om, at man gerne vil have mere strategisk ledelse i bibliotekerne Der skal udvikles strategier og udviklingsplaner. Legitimitet knyttes til den evne, lederne har til at skabe strategisk udvikling. Dette stemmer i øvrigt fint overens med både konklusionerne på lederundersøgelsen (Johannsen og Pors, 2001, Pors,
2004) og indholdet i lederuddannelserne, der blev gennemført i perioden 2000-2004.

I Brunsson og Sahlin-Anderssons terminologi er lovens $\S 3$ stk. 3 et udtryk for en politik der skal styrke det administrative hierarki og svække rammerne for bibliotekarprofessionens magt i bibliotekerne.

Vi ser her, hvordan biblioteksvæsenet svarer på en NPM-præget forandring i loven ved at fokusere på kompetenceudvikling inden for feltet, et begreb som hidrører omstilling. Således kan man argumentere for, at bibliotekarerne har grebet chancen og videreudviklet deres ledelseskompetencer og dermed bemægtiget sig lederstillingerne. Man kan også fortolke situationen som, at lederuddannelserne prøver at koble den professionelle og den fagprofessionelle ledelse for at fastholde bibliotekarerne som ledere i bibliotekerne, og dermed overvinde modsætningen mellem ledelse og profession. I relation til dette er det en pointe, at der i dag, kun er ansat ganske få folkebiblioteksledere som ikke også er uddannede bibliotekarer. Der blev således ikke tale om en invasion af "djøfere" i de danske folkebiblioteker. $§ 3$ stk. 3 har således i højere grad sat ledelse (og lederuddannelse) på dagsordenen, end det har haft konsekvenser for, hvem der rent faktisk bestrider posterne som ledere på folkebibliotekerne.

Administrative ledere uden bibliotekarisk baggrund er således ikke blevet institutionaliseret i biblioteksvæsenet. Bibliotekarerne har imødegået dette ved selv at efteruddanne sig, og har stort set stadig monopol på lederstillingerne i folkebibliotekerne. Dette kan ses som udtryk for, at professionen forsøger at fastholde sin dominans i institutionen. Men det kan også ses som et udtryk for, at biblioteksvæsenets arbejde med at institutionalisere de nye ledelsesformer. Disse to forhold er ikke uforenelige. Dette underbygges i høj grad af BF's lederundersøgelser, som viser, at bibliotekslederne har bevæget sig fra et mere driftsorienteret fokus til større opmærksomhed på strategisk ledelse, og at langt størstedelen af lederne lægger stor vægt på formel lederuddannelse (Johannsen \& Pors, $2001 \&$ Pors, 2004).

Forandringen af lovens ordlyd vedrørende folkebibliotekernes ledelse og biblioteksvæsenets modtagelse af den er et eksempel på et møde mellem NPM-logikken og Bibliotekarlogikken. I det følgende analyseres mødet mellem de to logikker i forbindelse med 
effektiviseringstiltag i to folkebiblioteker, dvs. en analyse på organisationsniveau.

\section{Organisatoriske forandringer i folkebiblioteker}

I forbindelse med min Ph.d.-afhandling (Kann-Christensen, 2009) har jeg interviewet et antal ledere og bibliotekarer vedrørende to bibliotekers organisationsudvikling. I det følgende betegnes disse to biblioteker Bibliotek A og Bibliotek B. De foretagne interviews drejede sig blandt andet om lederes og bibliotekarers forskellige opfattelser af begrundelser for og effekterne af de gennemførte organisationsforandringer. Generelt kan man sige, at lederne begrundede nødvendigheden af forandring delvist med udgangspunkt i en NPM-logik. Bibliotekerne måtte forandre sig, dels for at tilpasse sig et marked og dels for at blive mere effektive; at komme så langt som muligt med de ressourcer, der er til rådighed $\mathrm{i}$ systemet. Denne effektivitet kunne, ifølge lederne, opnås ved at skabe en fleksibel organisation. Fleksibiliteten bestod i, at skabe en ensartet organisation, hvor medarbejderne er fleksible. Dette er således en fremtrædende begrundelse for at skabe teams. Teams er på begge de undersøgte biblioteker den måde driften er organiseret på. NPM-logikken bliver i dette forhold udfordret af bibliotekarlogikken. Ledernes ønske om fleksibilitet sker, ifølge bibliotekarerne, på bekostning af den bibliotekariske faglighed (KannChristensen, 2009).

Ønsket om at skabe en fleksibel og ensartet organisation kan som beskrevet identificeres i begge biblioteker. Det ideelle bibliotek (i organisatorisk sammenhæng) fremstilles i ledernes udsagn som præget af ensartede brugertilbud og fleksibilitet i forhold til ledelsens mulighed for at allokere personaleressourcer effektivt. Også en ensartet organisationskultur fremhæves som vigtig. På begge biblioteker beskriver ledelsen det problematiske i en stærk afdelingsopdelt kultur. Den afdelingsopdelte kultur beskrives som barrierer for forandring, og arbejde på tværs. Det er vigtigt at påpege, at ønsket om ensartede tilbud og fleksibilitet begrundes i lånerbehov. Legitimering med henvisning til lånerbehov er karakteristisk for den bibliotekariske logik, uden at der dog er dokumentation for at lånerne egentlig ønsker denne ensartethed. Det er karakteristisk at brugernes ønsker er uklart defineret. Således er lederne altså ikke kun repræsentanter for en effektivitetsorienteret NPM-lo- gik. Begrundelserne for forandring henter deres tyngde med henvisning til brugerne.

I fraværet af dokumentation for brugerønsker om et ensartet frem for et differentieret tilbud er det nærliggende at søge andre forklaringer på ønsket om et ensartet tilbud. Fordelen ved en ensartet organisation, som ikke er domineret af subkulturer, er at den er forudsætningen for den fleksible organisation.

Fleksibiliteten sikres i Bibliotek A dels via udviklingsorganisationen, som er projektorganiseret og dels ved at ledelsen forbeholder sig ret til at omplacere medarbejdere (bibliotekarer) i de forskellige afdelinger. I dette bibliotek kan man som bibliotekar altså ikke være sikker på at blive ved med at være børnebibliotekar selv om man oprindelig var blevet ansat i børnebiblioteket. Også i Bibliotek B berettes fra ledelsen om nødvendigheden af fleksibilitet. Her omplacerer man ikke bibliotekarerne permanent, men sikrer fleksibiliteten ved at pålægge bibliotekarerne at fungere som afløsere på tværs af afdelinger. Det ene sted tages således den fulde konsekvens af den oplevede nødvendighed af intern organisatorisk mobilitet, hvor man det andet sted oplever samme behov for mobilitet, men her bibeholdes tilhørsforholdet til teamet. Om denne forskel bunder i forskelligt ressourcepres eller forskelle i omstillingsvillighed er ikke enkelt at afgøre.

I det empiriske materiale fremkommer et interessant skisma mellem effektiv ressourceudnyttelse og optimal service. Ledelserne begge steder italesætter et behov for effektiv ressourceudnyttelse med henvisning til et krav om besparelser på personale. Begge biblioteker har i forbindelse med de organisatoriske forandringer måtte spare mange stillinger væk. Med et mindre personaleforbrug må det tilbageblevne personale være mere fleksibelt. Det kræver at personalets ressourcer udnyttes effektivt. Det er en traditionel ledelsesopgave at allokere ressourcer og sørge for en effektiv drift. Og det er i dette tilfælde den effektive drift der er i fokus, ikke sikringen af kvaliteten af denne drift, som man også kunne argumentere for er en ledelsesopgave. Dette er et eksempel på ledelsens NPM-logik.

Bibliotekarerne har en anden position i organisationen. Deres betragtninger om den fleksible organisation er domineret af en bekymring for om deres faglighed, som er knyttet til kvaliteten af den service, de 
yder lånerne udvandes. Bibliotekarernes argumenter imod den øgede fleksibilitet (dvs. at de konkret enten bliver flyttet og /eller at de skal afløse i andre afdelinger /teams) kan inddeles i to kategorier. Dels udtrykkes der bekymringer vedrørende deres egen faglige identitet og dels udtrykkes der bekymringer som er knyttet til arbejdsmiljøet. Således kan der identificeres to forskellige svar/reaktioner på ledelsens ønske om fleksibilitet. Et faglighedsperspektiv og et arbejdsmiljøperspektiv. I det følgende fokuserer jeg udelukkende på faglighedsperspektivet. Afsluttende diskuterer jeg hvorvidt bibliotekarernes værdier er i forandring,

I de interview som blev foretaget med bibliotekarerne på de to biblioteker, berørtes flere gange konsekvenserne af flytningerne. Bibliotekarernes udsagn peger i retning af, at bibliotekarens egen forestilling om faglighed, og det "man gerne vil" er knyttet til den gode service og den gode formidling over for den bestemte målgruppe, som den pågældende bibliotekar har erfaring med. Der betones, i forbindelse med oplevelsen af ikke at kunne formidle lige så godt som de erfarne bibliotekarer fra fx børnebiblioteket, en anerkendelse af kollegerne i børnebiblioteket, hvilket er interessant fordi det nedtoner de negative konnotationer, som findes i ledelsens opfattelse af subkulturerne, nemlig det forhold at de forskellige afdelinger mere eller mindre lå i krig med hinanden. Bibliotekarernes udsagn udtrykker en respekt for forskelligheden i fagligheden.

Også hensynet til lånerne betones i interviewene. Ifølge den bibliotekariske logik, giver det ensartede og fleksible bibliotek ikke nødvendigvis en bedre service. Hvis man tager eksemplet med børnebiblioteket igen, fremgår det at børnebibliotekaren sympatiserer med børnene. En bedre service knytter sig til en indlevelse $\mathrm{i}$ børnene som målgruppe og muligheden for at praktisere en bibliotekarisk faglighed (Kann-Christensen, 2009).

Skismaet mellem at være specialist og generalist tages også under behandling af bibliotekarerne. Der udtrykkes en frustration over, at man i fleksibilitetens og effektivitetens navn bliver en dårligere specialist - en dårligere kulturformidler. Bibliotekarernes udsagn viser for det første en tydelig forankring i den klassiske kulturformidleridentitet (Ørom, 1993) og for det andet en frustration over ledelsens ønske om fleksibilitet, som stammer fra en NPM-logik. Med
Brunsson og Sahlin-Anderssons påstand om NPMlogikkens formål (at underminere det professionelle hierarki) in mente, kan ledelsens begrundelser for, at ville flytte rundt på bibliotekarerne (de professionelle specialister) og dermed gøre dem til generalister betragtes som et led i denne strategi. Bibliotekarernes modstand mod dette betragtes som en gruppe professionelle der, med deres egen bibliotekarlogik som våben, kæmper for at beholde det. (Brunsson \& Sahlin-Andersson, 2005)

De forskelligartede italesættelser af behovet for fleksibilitet illustrerer en kamp mellem to konkurrerende værdisæt. Både ledere og bibliotekarer udtrykker støtte til ønsket om at forbedre servicen. Men begrebet service tilskrives forskelligt indhold af de to grupper:

Lederne italesætter behovet for bedre ressourceudnyttelse, og det stemmer overens med lederrollen som den der skal sørge for at fremme effektivisering i organisationen i tråd med NPM-logikken. Den fleksible organisation er instrumentet til effektiv ressourceudnyttelse, men den fleksible organisation er kun mulig, hvis den kobles til et ensartet bibliotekstilbud. Det ensartede bibliotekstilbud begrunder lederne både i bibliotek $\mathrm{A} \mathrm{og} \mathrm{B}$ med, at lånerne skal møde et bibliotek, som fremstår som ét hus, ét tilbud, én åbningstid. Det står i modsætning til afdelingernes subkulturer og stædige specialiserede fagligheder, som af lederne opleves, som barrierer for fleksibilitet og effektiv ressourceudnyttelse i biblioteket.

Trods anderledes begrundelser viser det sig imidlertid, at bibliotekarerne ikke automatisk er modstandere af det ensartede bibliotekstilbud som sådan. Der er forståelse blandt bibliotekarerne for, at man i Bibliotek $\mathrm{B}$ fx harmoniserer åbningstider og nedlægger de afdelingsopdelte skranker. Men kravet om fleksibilitet møder modstand begge steder. Fleksibilitetskravet opleves mere dramatisk i Bibliotek A end Bibliotek B. I Bibliotek A flytter man medarbejdere til nye afdelinger permanent, i Bibliotek B skal man blot være parat til at afløse i hinandens afdelinger. Men modstanden mod den fleksible organisation samler sig om de samme temaer begge steder. Hos bibliotekarerne begrundes modstanden med henvisning til den samme låner, som ledelsen anvendte som legitimitetsgrundlag for det ensartede bibliotek. Men bibliotekarernes tolkning af lånernes præferencer er farvet af deres egen fagprofessionelle logik, nemlig at lå- 
nerne har krav på en service der er præget af erfaring og fagspecifik. Der er forskel på børnefaglighed og musikfaglighed. Bibliotekarlogikken og NPM-logikken tager således begge lånerne til indtægt, når de begrunder det positive eller negative aspekt af forandringerne. De to logikker fokuserer på væsentlige men forskellige sider af lånerens behov.

Til slut skal det nævnes, at der på Bibliotek A fremtræder udsagn, som peger på, at bibliotekarerne også erkender nødvendigheden af deres egen fleksibilitet. I forbindelse med en permanent flytning er man ærgerlig over at sige farvel til en særlig faglighed, der knytter sig til det område man kommer fra, men det at man kan flyttes opleves også som noget positivt. Dette viser, at de pågældende bibliotekarer opfatter omstillingsparathed som en værdi i sig selv. Den enkelte bibliotekars værd er ikke udelukkende knyttet en traditionel faglighed, men kan øges ved forandringsvillighed. Således anskues omstillingsparathed ikke per definition i modstrid med den bibliotekarprofessionelle logik, men kan bidrage til at omforme den bibliotekariske logiks indhold og normer. Begrebet faglighed viser sig som et åbent begreb, der under ydre pres kan besættes med forskelligt indhold og dermed omformes. Denne pointe er kernen i Andersen og Born (2001), at den offentligt ansatte i stigende grad værdsættes for fleksibilitet og omstillingsparathed.

\section{Diskussion}

Hvad er sammenhængen mellem biblioteksfeltets strategi i forhold til åbningen for nye ledere i bibliotekerne og mine analyser af udsagn fra konkrete organisationsudvklingsprojekter?

Når et felt møder en ny logik, på det regulative niveau, må man tage kampen op. I biblioteksvæsenet har feltets strategi været, at uddanne de eksisterende bibliotekar-ledere for fortsat at kunne legitimere bibliotekarer som bibliotekschefer. Både centrale aktører så som daværende Biblioteksstyrelsen, BF, Danmarks Biblioteksforening og Danmarks Biblioteksskole satsede kraftigt på uddannelse af bibliotekarer til ledere (Kann-Christensen, 2006). Ligesom bibliotekslederne har anvendt forskellige tilbud om efteruddannelse (Pors, 2005). Dette peger på, at NPM-logikken dels er blevet mødt med modstand - Strategien har betydet at der ikke sidder djøfere på landets folkebibliotekers lederposter - men også at bibliotekar-lederne i højere grad er blevet ledere med stort L. (Pors, 2005, Kann-Christensen, 2009)

På organisationsniveau er det nu lederne der står for NPM-logikken. Djøferne er blevet overflødige. Derfor ser man på organisationsniveau, at kampen mellem NPM-logikken og bibliotekarlogikken er blevet en kamp mellem ledere og bibliotekarer. Men både ledernes og bibliotekarernes identitet formes af NPM-logikken.

Ledernes forestillinger om "det vigtige" er mere præget af NPM-logikken end bibliotekarernes. Dog kan ledernes forestillinger ikke udelukkende knyttes til NPM-logikken. Begge de undersøgte bibliotekers ledere er uddannede bibliotekarer, og det er tydeligt mange steder i det empiriske materiale, at bibliotekslederne har særdeles god føling med de faglige problemstillinger. I beskrivelserne af lederne har jeg undervejs primært betonet NPM-logikken. Og den træder da også tydeligt frem mange steder. Dette, antager jeg, skyldes, at ledelse simpelthen er den opgave, som de pågældende skal løse. Desuden kan det skyldes, at jeg har interviewet dem som ledere. At det har været passende $\mathrm{i}$ interviewsituationen at performe deres lederidentitet (Järvinen, 2005). Når dette forbehold er taget, så vil jeg pege på, at ledernes forestillinger om organisatoriske forandringer er præget af en NPM-logik, som gør at lederne fokuserer på effektivitet i driften, omstilling og udvikling $\mathrm{i}$ forhold til bibliotekernes placering i forhold til andre kulturtilbud og deres rolle og størrelse i kommunen.

Bibliotekarernes traditionelle fagidentitet, som den er beskrevet af Anders Ørom (1993), er også under forandring. På den måde er bibliotekarerne i mange forhold omstillingsparate og udviklingsorienterede. De accepterer de NPM-inspirerede organisationsudviklingsprojekter og de oplevede effekter af dem i vid udstrækning. Men den bibliotekariske logik former deres forestillinger om dem på en anden måde end ledernes. Der hvor den bibliotekariske modstand er tydeligst, er dels når de oplever, at den forandrede organisation fratager dem muligheden for at udøve deres faglighed på den måde, som de selv anser for mest forsvarlig, og når den nye beslutningsstruktur fratager dem indflydelse på strategiske beslutninger. Således kan der både på feltniveau og på organisationsniveau identificeres en bibliotekarprofession, som betragter brugerkontakt, formidling af viden og kultur som det afgørende, samtidig med at professionen 
ikke principielt øver modstand mod hverken konkurrence, effektivitet eller krav om kontinuerlig fornyelse i biblioteksvæsenet. Men analysen viser også, at lederne står i en vanskelig situation. Når der ikke er ressourcer til at gøre bibliotekarerne tilfredse, når der helt konkret mangler en bibliotekar i en afdeling, og de der er til rådighed ikke oplever at de kan eller har lyst til at løfte opgaven så står man som leder i et krydspres. Et krydspres mellem NPM-logikken og bibliotekarlogikken.

Analysen af mødet mellem NPM-logikken og Bibliotekarlogikken er væsentlig både for den videre forskning om folkebiblioteker og for praksis. I forhold til biblioteksforskningen er det væsentligt at være bevidst om legitimitetskrav og effektivitetsnormer, når man analyserer biblioteket som institution. I forhold til praksis kan viden om de forskellige gruppers forestillinger om biblioteket være afgørende for at kunne agere målrettet i feltet.

\section{Note}

1. Denne artikel er skrevet med udgangspunkt i min Ph.d.-afhandling: Forestillinger om forandring (Kann-Christensen, 2009).

\section{Referencer}

Andersen, NA, \& Born, AW (2001). Kcerlighed og omstilling : Italescettelsen af den offentligt ansatte. København: Nyt fra Samfundsvidenskaberne.

Andersson, M \& Skot-Hansen, D (1994). Det lokale bibliotek: Afvikling eller udvikling. København: Danmarks Bibliotekesskole og Udviklingscenteret for folkeoplysning og voksenundervisning.

Audunson, R (1996). Change processes in public libraries: A comparative project within an institutionalist perspective. ( $\mathrm{PhD}$, Oslo Universitet, Department of Political Science).

Audunson, R (1999). Between professional field norm and environmental change impetuses : A comparative study of change processes in public libraries. Library \& Information Sience Research, 21(4), 523-552.

Audunson, R (2001). Folkebibliotekernes rolle i en digital fremtid: Publikums, politikernes og bibliote- karenes bilder. I: R. Audunson, \& N. Lund (Eds.), Det siviliserte informasjonssamfunn: Folkebibliotekernes rolle ved inngangen til en digital tid (pp. 206224). Bergen: Fakbokforlaget Vigmostad og Bjørke.

Audunson, R \& Lund, N (Eds.). (2001). Det siviliserte informasjonssamfunn: Folkebibliotekenes rolle ved inngangen til en digital tid. Bergen: Fakbokforlaget Vigmostad og Bjørke.

Bentsen, BZ, Borum, F, Erlingsdóttir, G \& Sahlin Andersson, K (Eds). (1999). Når styringsambitioner møder praksis: -den svcere omstilling af sygehus og sundhedsvasenet i Danmark og Sverige.

Biblioteksstyrelsen (2004). Udviklingen i folkebibliotekernes virksomhed og økonomi 1994-2002 : Med sarligt henblik på evaluering af lov om biblioteksvirksomhed (2000) Lokaliseret 13.02.2009, .http:// www.bs.dk/publikationer/andre/udviklingen/pdf/udviklingen.pdf

Brunsson, N \& Sahlin-Andersson, K (2005). Inte bara mode. att skapa organisationer i offentlig sektor. I: T. Busch, E. Johnsen, K. K. Klausen \& J. O. Vanebo (Eds.), Modernisering av offentlig sektor: Utfordringer, metoder og dillemaer (2 udg., pp. 82-95). Oslo: Universitetsforlaget.

Brücker, T \& Høy, E (2003). New public management: Udfordring eller trussel? Bibliotekspressen, (1), 6-9.

Busch, T, Vanebo, JO, Klausen, KK \& Johnsen, E (Eds.). (2005). Modernisering av offentlig sektor: Utfordringer, metoder og dilemmaer. Oslo: Universitetsforlaget.

Dahler Larsen, P (1998). Den rituelle refleksion: Om evaluering i organisationer. Odense: Odense Universitetsforlag.

DiMaggio, PJ \& Powell, WW (1991). The iron cage revisited: Institutional isomorphism and collective rationality. I: W. W. Powell, \& P. J. DiMaggio (Eds.), The New Institutionalism in Organizational Analysis (pp. 63-82). Chicago: University of Chicago Press.

Ejersbo, N \& Greve, C (2005). Moderniseringen af den offentlige sektor. København: Børsens forlag. 
Emerek, L (2001). At skrive bibliotekshistorie. I: R. Audunson, \& N. Lund (Eds.), Det siviliserte informajonssamfunn: Folkebibliotekernes rolle ved inngangen til en digital tid (pp. 88-117). Bergen: Fagbokforlaget Vigmostad og Bjørke.

Emerek, L (2006). Indledning. I: L. Emerek, C. Hvenegaard Rasmussen \& D. Skot-Hansen (Eds.), Folkebiblioteket som forvandlingsrum: Perspektiver på folkebiblioteket i kultur og medielandskabet (pp. 6-10)

Emerek, L, Hvenegaard Rasmussen, C \& Skot-Hansen, D (Eds.). (2006). Folkebiblioteket som forvandlingsrum: Perspektiver på folkebiblioteket $i$ kultur og medielandskabet. København: Danmarks Biblioteksforening og Danmarks Biblioteksskole.

Evald, P (2007). Organisations- og systemudvikling i folkebibliotekerne 1900-2000. Dansk Biblioteksforskning, 3(1), 17-30.

Friedland, R \& Alford, R (1991). Bringing Society back in: Symbols, Practises and Institutional Contradictions. I: W. W. Powell, \& P. J. DiMaggio (Eds.), The new institutionalism in organizational analysis (pp. 232-263). Chicago: The University of Chicago Press.

Greenwood, R \& Hinings, CR (1993) Understanding strategic change: The contribution of archetypes. Academy of Management Journal 36(5). (pp. 10521081)

Hedemark, Å, Hedman, J \& Sundin, O (2005). Speaking of users: On user discourses in the field of public libraries. Information Research, 10(2)

Jarlov, S \& Melander, P (2005). Statens økonomistyringsdiskurs - forklædte managementreformer, velafrettet ledelsesretorik og indkapslet arbejdspraksis. I: T. Busch, E. Johnsen, K. K. Klausen \& J. O. Vanebo (Eds.), Modernisering av offentlig sektor (pp. 107128). Oslo: Universitetsforlaget.

Jochumsen, H \& Hvenegaard Rasmussen, C (2006). Folkebiblioteket under forandring: Modernitet, felt og diskurs. København: Danmarks biblioteksforening og Danmarks Biblioteksskole.
Johannsen, CG \& Pors, NO (2001). Ledere og ledelse i danske biblioteker. Frederiksberg: Bibliotekarforbundet.

Järvinen, M (2005). Interview i en interaktionistisk begrebsramme. I: M. Järvinen, \& N. Mik-Meyer (Eds.), Kvalitative metoder $i$ et interaktionistisk perspektiv : Interview, observationer og dokumenter (pp. 27-48). København: Hans Reitzels forlag.

Kann-Christensen, N (2006). At trække på samme hammel - formål og indsatsområder for to udviklingspuljer i Danmarks biblioteksvæsen. Dansk Biblioteksforskning, (2), 31-42.

Kann-Christensen, N \& Andersen, J (2009) Developing the library: Between efficiency, accountability and forms of recognition. I: Journal of Documentation. 65( 2) 208-222.

Kann-Christensen, N (2009). Forestillinger om forandringer : Organisatoriske forandringer I to danske folkebiblioteker (Ph.D. Danmarks Biblioteksskole).

Klausen, KK (2005). Fra public administration over new PA til NPM - en fortolkningsramme for reformer. I: T. Busch, E. Johnsen, K. K. Klausen \& J. O. Vanebo (Eds.), Modernisering av offentlig sektor: Utfordringer, metoder og dilemmaer (2. udg., pp. 5369). Oslo: Universitetsforlaget.

Lov Nr. 1100 Af 22/12/1993 Lov Om Folkebiblioteker m.v. (1993).

Lov Nr. 340 Af 17/05/2000 Lov Om Biblioteksvirksomhed, (2000).

Pors, NO (2004). Ledere og ledelse i danske folkebiblioteker. Frederiksberg: Bibliotekarforbundet.

Pors, NO (2005). Mellem identitet og legitimitet : Forandringer, kultur og ledelse i danske folkebiblioteker. København: Danmarks Biblioteksskole.

Pors, NO (2006). Organisationsopskrifter og folkebibliotekerne. Dansk Biblioteksforskning, 2(1), 5-15.

Reay, T \& Hinings, CR (2005). The recomposition of an organizational field: Health care in Alberta. Organization Studies, 26(3), 351-384. 
Røvik, KA (1998). Moderne organisasjoner: Trender $i$ organisajonstenkningen ved tusindårsskiftet.

Bergen: Fakbokforlaget Vigmostad og Bjørke.

Røvik, KA (2005). Trender og Translasjoner: Iddeer som former det 21. Arhundredes organisasjon. Oslo: Universitetsforlaget.

Schreiber, T (2006). Bibliotekarprofessionen siden 1960'erne. I: T. Schreiber, \& H. Elbeshausen (Eds.), Bibliotekarerne. en profession i et felt af viden, kommunikation og teknologi (pp. 15-47). København: Samfundslitteratur.

Schreiber, T \& Elbeshausen, H (Eds.). (2006). Bibliotekarerne. en profession i et felt af viden, kommunikation og teknologi. København: Samfundslitteratur.

Skouvig, L (2006). Hvordan bibliotekaren opstod - et historisk perspektiv på bibliotekarprofessionen i danmark i perioden 1880-1920. I: T. Schreiber, \& H. Elbeshausen (Eds.), Bibliotekarerne. en profession $i$ et felt af viden, kommunikation og teknologi (pp. 4776). København: Samfundslitteratur.

Suddaby, R \& Greenwood, R (2005). Rhetorical strategies of legitimacy. Administrative Science Quarterly, (50), 35-67.

Sundin, O. Informationskompetence, ikt og bibliotekarers professionelle ekspertise I: T. Schreiber, \& H. Elbeshausen (Eds.), Bibliotekarerne. en profession $i$ et felt af viden, kommunikation og teknologi (pp. 7796). København: Samfundslitteratur.

Thornton, P \& Ocasio, W (2008). Institutional logics. I: R. Greenwood, C. Olivier, K. Sahlin-Andersson $\&$ R. Suddaby (Eds.), The Sage handbook of organizational institutionalism (pp. 99-129). Los Angeles, London, New Delhi, Singapore: Sage.

Ørom, A (1993). Bibliotekariske identiteter, formidlingsarbejde og arbejdsorganisering. Biblioteksarbejde (39), 37-43. 